\title{
A szívizom-diszfunkció echokardiográfiás vizsgálata diabéteszben
}

\author{
Hajdu Máté, Maren Oedven Knutsen oh., Faludi Réka
}

\author{
Pécsi Tudományegyetem, Klinikai Központ, Szívgyógyászati Klinika, Pécs \\ Levelezési cím: \\ Dr. Hajdu Máté, 7624 Pécs, Ifjúság u. 13. E-mail: hajdu.mate@pte.hu
}

\begin{abstract}
A cukorbetegség világszerte növekvő egészségügyi problémát jelent. A legtöbb halálesetért a kardiovaszkuláris szövődmények tehetők felelőssé ebben a kórképben. A betegség elörehaladása során a szívizom-diszfunkció a szív minden üregét érinti, korai szürése így kiemelkedő jelentőségü a diabéteszes populációban. Szöveti Doppler és speckle tracking alapú strain mérésekkel a diabéteszes cardiomyopathia korai jelei is felfedezhetök. Az irodalmi adatok szerint a szigorú glikémiás kontroll a legfontosabb terápiás cél a szívizom-érintettség megelözése érdekében. Összefoglalásunk célja, hogy bemutassa a diabéteszes cardiomyopathia patofiziológiáját, a szubklinikus szívizom-károsodás kimutatására szolgáló új echokardiográfiás módszereket, és az e módszerek segítségével nyert legfrissebb kutatási eredményeket.
\end{abstract}

Kulcsszavak: echokardiográfia, diabetes mellitus, szöveti Doppler, speckle tracking, strain

\section{Echocardiographic assessment of the myocardial dysfunction in diabetes}

The increasing prevalence of diabetes represents an emerging global health problem. Cardiovascular complications are responsible for the majority of deaths in this disease. Myocardial dysfunction affects all cardiac chambers, thus early screening of diabetes-related cardiac complications is crucial. Tissue Doppler and speckle tracking-derived strain technics allow the early diagnosis of diabetic cardiomyopathy. Recent studies suggest that strict glycaemic control is the most effective therapeutic approach to prevent cardiac complications in diabetes. The aim of our review is to demonstrate the pathophysiology of the diabetic cardiomyopathy, the new echocardiographic technics for the assessment of the subclinical myocardial involvement and the current findings obtained by the help of these modern techniques.

Keywords: echocardiography, diabetes mellitus, tissue Doppler, speckle tracking, strain

A cukorbetegség (diabetes mellitus - DM) krónikus szénhidrátanyagcsere-betegség, ami világszerte több százmillió embert érint. A DM a 9. leggyakoribb halálok a világon a 2019-es WHO-adatok alapján (1), ami a becslések szerint 2030-ra a 7. helyre lép elö a fejlett országokban (2). Prevalencia szempontjából kiegyenlített a nemek aránya, viszont a szövődmények kialakulásának esélye, valamint a mortalitás is magasabb férfiak esetében. A tavaly 50 éves fennállását ünneplö Magyar Diabetes Társaság 2016-ban megjelent vizsgálatának eredményei alapján 2014-ben Magyarországon 772 ezer beteg váltott ki vércukorcsökkentő gyógyszert, de a tényleges betegszám egymillió felettire tehető (3). Fontos megkülönböztetni a DM két legfontosabb típusát:

- az 1-es típusú DM (T1DM) általában gyermekvagy serdülökorban kezdődő, a hasnyálmirigy béta-sejtjeit pusztító autoimmun betegség (4).

- A 2-es típusú DM (T2DM) esetében inzulinrezisztencia alakul ki, a sejtek csak nagyobb mennyiségű inzulin hatására képesek felhasználni a glükózt. A betegek nagy része túlsúlyos. 
Az utóbbi kórkép jellemző rizikófaktorai között megtalálható a magas vérnyomás, dyslipidaemia, elhízás, dohányzás és a diabétesz családi halmozódása (3). A DM szövődményeinek kialakulása szempontjából alapvető fontosságú a betegség fennállásának hossza, a glikémiás kontroll minősége és az életkor $(5,6)$.

DM-ben a legtöbb halálesetért a kardiovaszkuláris események tehetök felelőssé $(7,8)$. Ennek alapja, hogy a DM több mechanizmuson keresztül is károsíthatja a szívmüködést (koszorúér-betegség, diabéteszes cardiomyopathia, kardiális autonóm neuropathia). Az egyik legismertebb szövődmény, az ateroszklerózis, érintheti a koszorúereket, de más verőereket is. 1974ben a Framingham Heart Study eredményei alapján bebizonyosodott, hogy a DM a szívelégtelenség független rizikófaktora, így külön entitásként kezelendő (9). A diabéteszes cardiomyopathia érdekessége, hogy olyan DM-es betegeknél is kialakul balkamra-hipertrófia, szívizom-fibrózis és szívelégtelenség, akiknél kizárható a koszorúér-betegség és a szívelégtelenség egyéb típusos okainak (billentyübetegség, hipertónia) jelenléte (10).

A kardiovaszkuláris szövődmények gyakoriak és jelentős mortalitással bírnak DM-ben, így a korai diagnózis felállítása igen fontos, hiszen az időben végrehajtott életmód-változtatás és gyógyszeres intervenció megelőzheti vagy késleltetheti a szívelégtelenség kialakulását (11).

Jelen összefoglalás célja, hogy bemutassa a diabéteszes cardiomyopathia patofiziológiáját, a szubklinikus szívizom-károsodás kimutatására szolgáló új echokardiográfiás módszereket, és az e módszerek segítségével nyert legfrissebb kutatási eredményeket.

\section{A diabéteszes cardiomyopathia patofiziológiája}

A diabéteszes cardiomyopathia patofiziológiája még nem teljesen ismert, de bizonyos, hogy multifaktoriális folyamatról van szó (1. ábra).

A krónikus hyperglykaemia számos metabolikus és molekuláris változást okoz a szívizomsejtben. Többek között a fokozott glükózmetabolizmus következtében nagy számban termelödnek reaktív oxigén szabadgyökök. A következményes oxidatív stressz csökkenti a szívizom kontraktilitását és végül fibrózishoz vezet. DNS-károsodás és a cardiomyocyta apoptózis felgyorsulása is bekövetkezhet. A szokásos biokémiai útvonalak kisiklása elörehaladott glikációs végtermékek (advanced glycation end-product, AGE) termelődéséhez vezet. Ezek kóros kémiai kötéseket alakítanak ki az extracellulárisan jelenlevő kollagén és elasztinfehérjékben, ily módon növelve a miokardiális stiffnesst és károsítva a szívizom relaxációját. A hexózamin-anyagcsereút aktiválódása a kalcium-homeosztázis károsodásához vezet, ami szintén a szívizom relaxációját károsítja.
Kalcium-homeosztázis változása

Szubsztrátfelhasználás kisiklásai Lipotoxicitás

Advanced glycation end-products

Mitokondriális funkciózavar

Fokozott oxidatív stressz

RAAS fokozott aktiválódása

Kardiális autonóm neuropathia

Szívizom-steatosis

Cardiomyocita apoptosis felgyorsulása

Morfológiai eltérések

BK koncentrikus remodel-

lingje majd hipertrófiája

Funkcionális eltérések

BK diasztolés

funkciózavar

BK longitudinális

szisztolés funkciójának

károsodása

BK kontraktilis rezerv

beszükülése

1. ÁBRA. A diabéteszes cardiomyopathia patomechanizmusa Ernande és munkatársai nyomán (19) (BK: bal kamra)

A renin-angiotenzin-aldoszteron rendszer aktiválódása is fokozódik krónikus hyperglykaemia hatására (12-14). Diabéteszben emelkedik a keringő szabad zsírsavak mennyisége is. Ez kóros lipidlerakódáshoz (steatosis) vezethet számos szervben, például a vázizomzatban vagy a májban. A szívizomban ez a folyamat úgynevezett lipotoxikus szívizom-károsodáshoz vezet: mitokondriális funkciókárosodás, fokozott apoptózis („lipoapoptózis") lép fel, a végeredmény pedig ismét csak a szívizom fibrózisa (15).

A hyperinsulinaemia és inzulinrezisztencia egyaránt jellemzik a T2DM-et és az azt megelőző prediabéteszes állapotot. A hyperinsulinaemia több módon is cardiomyocyta-hipertrófiához vezethet: serkenti a B-típusú nátriuretikus peptid termelődéséért felelős gén expresszióját, illetve transzkripciós faktorokon keresztül fokozza a celluláris és extracelluláris fehérje-expreszsziót. Az extracelluláris mátrixproteinek kóros felszaporodása fokális szívizom-fibrózist eredményez (16-18). Közismert, hogy a makrovaszkuláris károsodások mellett a diabétesz mikrovaszkuláris károsodásokhoz is vezet testszerte. Jellemző példák a diabéteszes retinopathia és nephropathia. Az endothel-diszfunkció és a koronáriaáramlási rezerv beszükülése a koszorúerekben is kialakulhat, akkor is, ha az epikardiális koszorúerek szignifikáns ateroszklerózisa nincs jelen. A mikrovaszkuláris iszkémia hozzájárul a stiffness fokozódásához, fibrózis kialakulásához és végső soron a szívizom diszfunkciójához $(12,19,20)$.

A kardiális autonóm neuropathia gyakori szövődménye a hosszú ideje fennálló cukorbetegségnek: A szívfrekvencia szabályozása és az érfalak vegetatív beidegzése károsodik. Jellegzetes a perifériás vaszkuláris 
rezisztencia emelkedése a fokozott szimpatikus tónus következtében. A folyamat a koszorúereket is érintheti, beszükitve a miokardiális perfúziós és kontraktilis rezervet (21-23).

A szubcelluláris, celluláris szintủ károsodások, az intersticiális és perivaszkuláris fibrózis végső soron a relaxáció károsodásához, a miokardiális stiffness fokozódásához vezetnek. A balkamra-hipertrófia ezután jelenik meg, míg a bal kamrai szisztolés funkció manifeszt károsodása csak a kórkép előrehaladott formájában jellemző $(12,24)$.

A legszélesebb körben elérhető és alkalmazott diagnosztikai eszköz a DM kardiális szövődményeinek felismerésére az echokardiográfia. Fiatal, társbetegségek nélküli T1DM-populációban azonban a klasszikus echokardiográfiás technikákkal az egészségesekével egyező értékek mérhetők (25). A szöveti Doppler (TDI) és föleg a speckle tracking alapú strain technika megjelenése tette lehetővé a minden szívüreget érintő, szubklinikus jellegủ szívizom-diszfunkció kimutatását diabéteszesekben.

\section{Bal kamrai szisztolés funkció szubklinikus károsodása}

A bal kamrai ejekciós frakció általában megtartottnak bizonyul diabéteszes betegekben $(12,19,20,25)$. A TDI-alapú mérések T1DM-populációban megtartott bal kamrai longitudinális szisztolés funkciót is igazoltak (11, 25). A speckle tracking technika ennél érzékenyebbnek bizonyult: a globális longitudinális strain (GLS) és globális cirkumferenciális strain (GCS) csökkenését számos kutatás igazolta fiatal, tünetmentes T1DM-betegekben (26-29). Razaky és munkatársainak eredményei alapján hagyományos echokardiográfiás vizsgálattal észrevehetetlen, korai bal kamrai szisztolés diszfunkció mutatható ki 3D speckle tracking technika segítségével tünetmentes T1DM-es gyermekekben (28). Hasonlóképpen, Bakhoum és munkatársainak kutatásai során fiatal T1DM-páciensek bal kamrai GLS-e szignifikánsan alacsonyabbnak bizonyult az azonos ejekciós frakciójú egészséges kontrollokkal összehasonlítva (26). Jędrzejewska és munkatársai a GLS- és GCS-paraméterek szignifikáns károsodását is bizonyították fiatal felnőtt T1DM-betegekben (29). Ezzel ellentétben Hensel és munkatársai emelkedett longitudinális és cirkumferenciális strain rate értékeket igazoltak T1DM-ben szenvedő gyermekekben és fiatal felnőttekben, ami nyugalomban és terhelésre egyaránt észlelhető volt, és kifejezettebben jelentkezett a régebb óta betegekben. Az eredmények alapján felvetették, hogy egyfajta hiperdinám keringés jellemzi a fiatal T1DM-populációt. Ugyanakkor a GLS- és GCS-értékek nem mutattak eltérést a kontrollokhoz képest ugyanebben a populációban, sem nyugalomban, sem terhelésre (30).

Jørgensen és munkatársai T2DM-populációt vizsgálva csökkent GLS-t találtak megtartott ejekciós frakció mellett, ami azonban nem mutatott összefüggést a betegség fennállásának hosszával (31).

\section{Bal kamrai relaxáció károsodása}

A TDI-alapú vizsgálati módszerek bevezetése előtt a bal kamra diasztolés funkciózavarát a mitralis beáramlási görbe elemzésével próbálták leírni, azonban világossá vált, hogy ez a paraméter önmagában nem alkalmas a bal kamrai relaxáció és a töltőnyomás megítélésére. A jelenlegi diagnosztikus algoritmusokban a szöveti Doppler-paraméterek már kulcsszerepet játszanak, ám a kapott eredmények továbbra is ellentmondásosak, mivel a különböző munkacsoportok gyakran eltérő módon értelmezik az ajánlásokat. Jørgensen és munkatársai a T2DM-populációban észlelhető bal kamrai remodellinget a szív felgyorsult öregedéseként jellemezték, ami emelkedett bal kamrai stiffness és falvastagság, valamint diasztolés diszfunkció kialakulásával jár (31). Egy friss metaanalízis eredményei alapján a diasztolés funkciózavar a T2DM-populáció közel 50\%-át érinti (32).

A T1DM-populáció esetében kevésbé egyértelmű a helyzet. Di Cori és munkatársai károsodott szisztolés strainértékeket írtak le több bal kamrai szegmentumban, ám nem találtak diasztolés funkciózavart panaszmentes T1DM-betegeik körében (33). Ugyanakkor számos más munkacsoport eredményei alapján T1DM-betegeknél a diabéteszes cardiomyopathia korai echokardiográfiás jele a diasztolés funkciózavar, ami megelőzheti a szubklinikus szisztolés funkciózavar kialakulását: Karamitsos és munkatársai TDI-mérésekkel a bal kamrában igazolták a diasztolés funkciózavar jelenlétét (csökkent mitralis e'), de kizárták a szisztolés funkciózavart (megtartott mitralis $S$ ) társbetegség nélküli T1DM-betegekben (34). Van Berendoncks és munkatársai idősödő T1DM-populációt vizsgáltak, amelyben magas volt a koszorúérbetegek aránya. E populáció $66 \%$-ában írtak le diasztolés funkciózavart, míg szubklinikus szisztolés funkciózavar (GLS alapján) csak a betegek 39\%-ában volt jelen (27). Patkánymodellben a T1DM-ben és T2DM-ben kialakuló diabéteszes cardiomyopathia között markáns különbségek kerültek leírásra: T1DM-ben a bal kamrai kontraktilitás és az aktív relaxáció károsodása volt a jellemző, míg T2DM-ben az emelkedett bal kamrai stiffness dominálta a képet (35).

\section{Jobblkamra-érintettség}

Karamitsos és munkatársai TDI méréseikkel a jobb kamrában is igazolták a diasztolés funkciózavar jelenlétét, de kizárták a szisztolés funkciózavart társbetegség nélküli T1DM-betegekben (34). Ahmed és munka- 


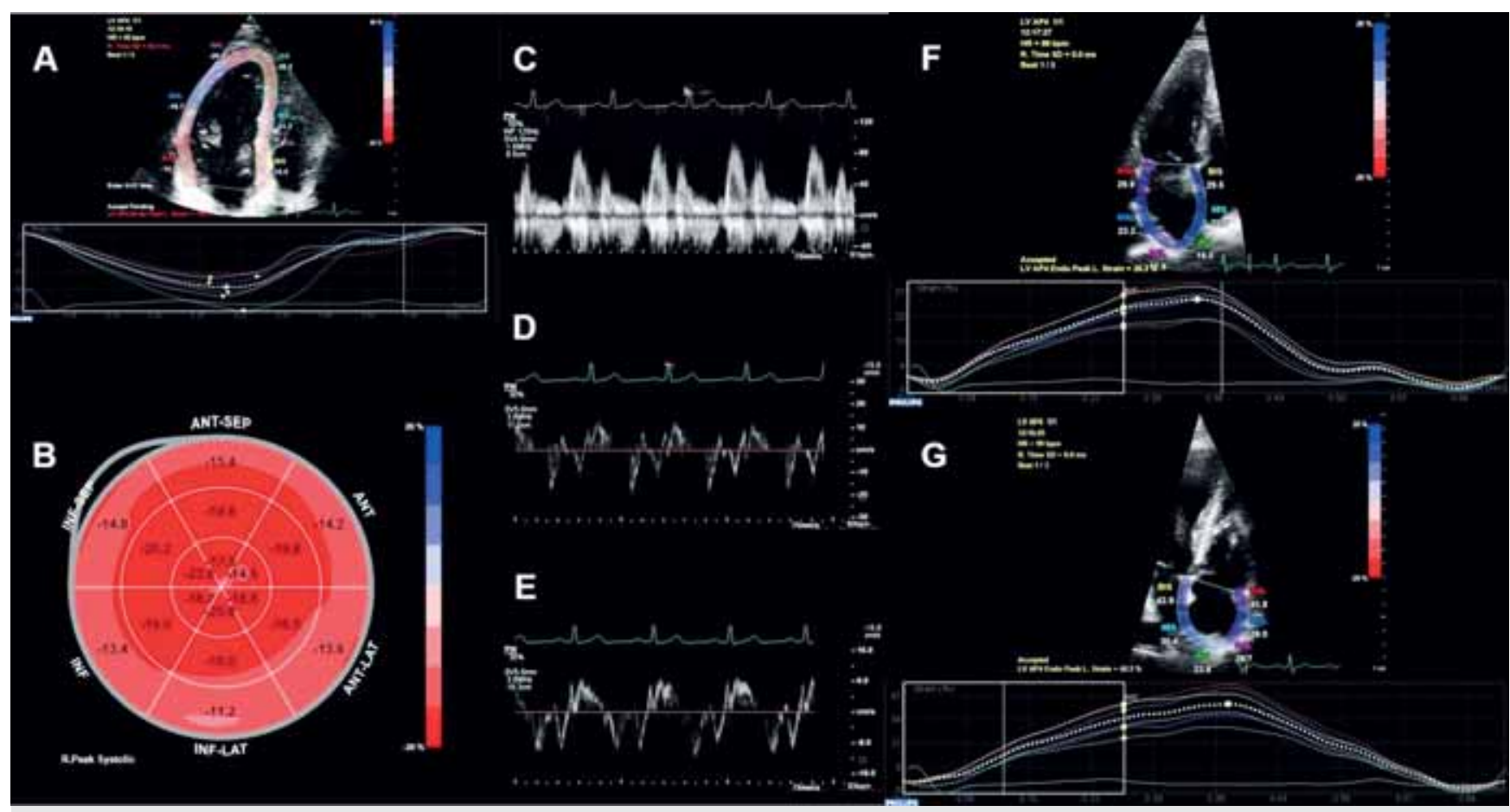

2. ÁBRA. 24 éves férfi beteg felvételei a szerzők saját anyagából. 9 éve ismert T1DM-je. Jelenleg inzulinpumpával kezelt. HbA ${ }_{1 c}$ értéke az echokardiográfiás vizsgálat időpontjában $8,6 \%$ volt. A: Bal kamrai strain vizsgálata, csúcsi négyüregi nézet. B: Bull's eye. Globális longitudinális strain értéke 17,5\%. A mitralis beáramlási görbe $(C)$ valamint a laterális $(D)$ és szeptális $(E)$ mitralis anuluson mért szöveti Doppler e' értékek megtartott bal kamrai relaxációra utalnak. A GLS mellett a bal (F) és jobb (G) pitvari rezevoár strainértékek is csökkentek az azonos korú kontrollpopulációval összehasonlítva

társai gyermek- és serdülőkorú T1DM-betegekben a jobb kamrai longitudinális szisztolés funkció károsodását igazolták TDI és strainmódszerekkel. A globális jobbkamra-funkció (RVFAC) és a relaxáció (tricuspidalis e') megtartottnak bizonyult (36). Kosmala és munkatársai strain és strain rate méréseikkel a szisztolés és diasztolés jobbkamra-funkció károsodását egyaránt leírták (37), míg Jȩdrzejewska és munkatársai a jobb kamrai szabad fali strain károsodásáról számoltak be társbetegségektől mentes T1DM-betegekben (29).

Tadic és munkatársai tünetmentes T2DM-betegeken végzett kutatásaik során károsodott jobb kamrai diasztolés funkció mellett a jobb kamrai longitudinális strain értékek csökkenését is leírták egészségesekhez viszonyítva. Utóbbi a jobb kamrai szabad fal minden (endo-, mio- és epikardiális) rétegét érinti (38).

\section{Pitvarméret és -funkció}

Nemes és munkatársai 3D méréseikkel a bal pitvari volumen szignifikáns növekedését írták le T1DM-betegekben (39). Acar és munkatársai volumetrikus méréseikkel a bal pitvar funkciójának megváltozását igazolták fiatal T1DM-es populációban: a pitvari konduit funkciót tükröző passzív ürülési frakció csökkent, míg a kontraktilis funkciót tükröző aktív ürülési frakció növekedett az egészséges populáció eredményeivel összehasonlítva
(40). A bal pitvari kontraktilis funkció kompenzatorikus jellegü javulása, ami a diasztolés funkciózavar kezdeti fázisában észlelhető, nemrégiben nyert igazolást pitvari strain vizsgálatok segítségével is, más kórképekben (41).

Ezzel összhangban T2DM-betegekben Tadic és munkatársai csökkent rezervoár és konduit strain mellett emelkedett kontraktilis strain értékeket írtak a bal és jobb pitvarban egyaránt (42).

\section{A szí vizom-diszfunkció kialakulását meghatározó tényezők}

Ha a DM szívre kifejtett hatásait kívánjuk tanulmányozni, a T1DM-betegek ideálisabb vizsgálati populációt jelentenek. Ezek a betegek ugyanis fiatalabbak, általában társbetegségektől mentesek, így a tisztán a DM által kifejtett kardiális hatások könnyebben tanulmányozhatók (2. ábra). Ennek ellenére a jelenleg elérhető kutatási eredmények ellentmondásosak. Jȩdrzejewska és munkatársainak kutatásai során a csökkent bal kamrai GLS egyetlen független prediktorának az emelkedett LDL-koleszterin-szint bizonyult. A DM fennállásának ideje ugyanakkor nem mutatott összefüggést a GLS-értékekkel (29). Van Berendoncks és munkatársai cikkében a visceralis zsír és a diasztolés vérnyomás bizonyultak a bal kamrai GLS független prediktorainak 
(27). Bakhoum és munkatársainak eredményei ugyanakkor arra utalnak, hogy a glikémiás kontroll minősége $\left(\mathrm{HbA}_{1 \mathrm{c}}\right)$ a $\mathrm{GLS}$ egyetlen független prediktora. A betegség fennállásának hossza és a GLS értéke között nem mutatkozott hasonló összefüggés (26). Hasonlóképpen, Grandi és munkatársai T1DM-populációban igazolták, hogy a szigorú glikémiás kontroll alkalmas a bal kamrai diasztolés funkciózavar megelözésére, vagy akár a visszafordítására is (43). Hensel és munkatársai tanulmányukban a $9 \%$ feletti $\mathrm{HbA}_{1 \mathrm{c}}$-értékekkel bíró betegeknél szignifikánsan csökkent GLS- és GCS-értékeket, és csökkent E/A arányt írtak le (30).

T2DM-populációt vizsgálva Tadic és munkatársai is a $\mathrm{HbA}_{1 \mathrm{c}}$-szint fontosságát emelték ki, ami szignifikáns összefüggést mutatott a bal pitvari konduit és rezervoár strain, valamint a jobb pitvari konduit és kontraktilis strain paraméterekkel (42). Egy későbbi, szintén T2DM-betegeket érintő vizsgálatuk során a $\mathrm{HbA}_{1 \mathrm{c}}$ a beszükült szívfrekvencia-variabilitás egyik független prediktorának bizonyult. Ezt az autonóm neuropathia részjelenségének tartották (38).

\section{Következtetések}

A diabéteszes cardiomyopathia a szív minden üregének funkcióját károsan befolyásolja. Bár egyelöre nem áll rendelkezésre ajánlás azzal kapcsolatban, hogy pontosan milyen helyzetekben indokolt a használatuk, az irodalmi adatok alapján a TDI és a speckle tracking alapú straintechnikák alkalmasak már a korai, szubklinikus szívizom-diszfunkció igazolására is. A legfrissebb eredmények arra utalnak, hogy a $\mathrm{HbA}_{1 \mathrm{c}}$ a szívizom-érintettség legfontosabb prediktora T1DM- és T2DM-populációban egyaránt. Ez felhívja a figyelmet a szigorú glikémiás kontroll fontosságára, ami kulcsszerepet játszik a szívizom-diszfunkció és a következményes szívelégtelenség megelőzésében.

\section{Nyilatkozat}

A szerzők kijelentik, hogy az összefoglaló közlemény megírásával kapcsolatban nem áll fenn velük szemben pénzügyi vagy egyéb lényeges összeütközés, összeférhetetlenségi ok, amely befolyásolhatja a közleményben bemutatott eredményeket, az abból levont következtetéseket vagy azok értelmezését.

\section{Irodalom}

1. WHO. The top 10 causes of death Fact sheet [Internet]. 2020. Available from: https://www.who.int/news-room/fact-sheets/detail/ the-top-10-causes-of-death

2. Mathers CD, Loncar D. Projections of global mortality and burden of disease from 2002 to 2030. PLoS Med 2006; 3(11): 1-20.

https://doi.org/10.1371/journal.pmed.0030442

3. Barkai L, Blatniczky L, Halmos T, et al. Nemzeti diabetesprogram 2011. Diab Hung 2011; 19(3): 1-39.

4. Stanescu DE, Lord K, Lipman TH. The Epidemiology of type 1 diabetes in children. Endocrin Metab Clin 2012; 41(4): 679-694. https://doi.org/10.1016/j.ecl.2012.08.001

5. Nathan DM. Long-term complications of diabetes mellitus. N Engl J Med 1993; 328(23): 1676-85. DOI: 10.1056/nejm199306103282306 6. Brink SJ. Complications of pediatric and adolescent type 1 diabetes mellitus. Curr Diabetes Rep 2001; 1: 47-55

https://doi.org/10.1007/s11892-001-0010-1

7. Zheng Y, Ley SH, Hu FB. Global aetiology and epidemiology of type 2 diabetes mellitus and its complications. Nat Rev Endocrinol 2018; 14: 88-98. https://doi.org/10.1038/nrendo.2017.151

8. Low Wang CC, Hess CN, Hiatt WR, et al. Clinical update: Cardiovascular disease in diabetes mellitus: Atherosclerotic cardiovascular disease and heart failure in type 2 diabetes mellitus - Mechanisms, management, and clinical considerations. Circulation 2016; 133 : 2459-2502. https://doi.org/10.1161/CIRCULATIONAHA.116.022194 9. Kannel WB, Hjortland M, Castelli WP. Role of diabetes in congestive heart failure: The Framingham study. Am J Cardiol 1974; 34(1): 29-34. https://doi.org/10.1016/0002-9149(74)90089-7

10. Rubler S, Dlugash J, Yuceoglu YZ, et al. New type of cardiomyopathy associated with diabetic glomerulosclerosis. Am J Cardiol 1972; 30(6): 595-602. https://doi.org/10.1016/0002-9149(72)90595-4

11. Kim EH, Kim YH. Left ventricular function in children and adolescents with type 1 diabetes mellitus. Korean Circ J 2010; 40(3): 125-130. https://doi.org/10.4070/kcj.2010.40.3.125

12. Pappachan JM, Varughese GI, Sriraman R, et al. Diabetic cardiomyopathy: Pathophysiology, diagnostic evaluation and management. World J Diabetes 2013; 4(5): 177-89.

https://doi.org/10.4239/wjd.v4.i5.177

13. Cai L, Li W, Wang G, et al. Hyperglycemia-induced apoptosis in mouse myocardium: Mitochondrial cytochrome c-mediated caspase-3 activation pathway. Diabetes 2002; 51(6): 1938-48.

https://doi.org/10.2337/diabetes.51.6.1938

14. Aragno M, Mastrocola R, Medana C, et al. Oxidative stress-dependent impairment of cardiac-specific transcription factors in experimental diabetes. Endocrinology 2006; 147(12): 5967-74.

https://doi.org/10.1210/en.2006-0728

15. Van De Weijer T, Schrauwen-Hinderling VB, Schrauwen P. Lipotoxicity in type 2 diabetic cardiomyopathy. Cardiovasc Res 2011; 92(1): 10-18. https://doi.org/10.1093/cvr/cvr212

16. Nunes S, Soares E, Fernandes J, et al. Early cardiac changes in a rat model of prediabetes: Brain natriuretic peptide overexpression seems to be the best marker. Cardiovasc Diabetol 2013; $12: 44$. https://doi.org/10.1186/1475-2840-12-44

17. Romano S, Di Mauro M, Fratini S, et al. Early diagnosis of left ventricular diastolic dysfunction in diabetic patients: A possible role for natriuretic peptides. Cardiovasc Diabetol 2010; 9: 89.

https://doi.org/10.1186/1475-2840-9-89

18. Feng B, Chen S, Chiu J, et al. Regulation of cardiomyocyte hypertrophy in diabetes at the transcriptional level. Am J Physiol Endocrinol Metab 2008; 294(6): E1119-26.

https://doi.org/10.1152/ajpendo.00029.2008

19. Ernande L, Derumeaux G. Diabetic cardiomyopathy: Myth or reality? Arch Cardiovasc Dis 2012; 105(4): 218-25.

https://doi.org/10.1016/j.acvd.2011.11.007

20. Lehrke M, Marx N. Diabetes Mellitus and heart failure. Am J Cardiol 2017; 120(1): 37-47. https://doi.org/10.1016/j.amjcard.2017.05.014 21. Pappachan JM, Sebastian J, Bino BC, et al. Cardiac autonomic neuropathy in diabetes mellitus: Prevalence, risk factors and utility of corrected QT interval in the ECG for its diagnosis. Postgrad Med J 2008; 84(990): 205-10. https://doi.org/10.1136/pgmj.2007.064048 22. Di Carli MF, Bianco-Batlles D, Landa ME, et al. Effects of autonomic neuropathy on coronary blood flow in patients with diabetes mellitus. Circulation. 1999; 100(8): 813-9.

https://doi.org/10.1161/01.cir.100.8.813

23. Taskiran M, Fritz-Hansen T, Rasmussen V, et al. Decreased myocardial perfusion reserve in diabetic autonomic neuropathy. Diabe- 
tes 2002; 51(11): 3306-10.

https://doi.org/10.2337/diabetes.51.11.3306

24. Campbell DJ, Somaratne JB, Jenkins AJ, et al. Impact of type 2 diabetes and the metabolic syndrome on myocardial structure and microvasculature of men with coronary artery disease. Cardiovasc Diabetol 2011; 10: 80. https://doi.org/10.1186/1475-2840-10-80

25. Palmieri V, Capaldo B, Russo C, et al. Uncomplicated type 1 diabetes and preclinical left ventricular myocardial dysfunction: Insights from echocardiography and exercise cardiac performance evaluation. Diabetes Res Clin Pract 2008; 79(2): 262-8.

https://doi.org/10.1016/j.diabres.2007.09.014

26. Bakhoum SWG, Habeeb HA, Elebrashy IN, et al. Assessment of left ventricular function in young type 1 diabetes mellitus patients by two-dimensional speckle tracking echocardiography: Relation to duration and control of diabetes. Egypt Hear J 2016; 68(4): 217-225. https://doi.org/10.1016/j.ehj.2016.02.006

27. Van Berendoncks AM, Van Gaal L, De Block C, et al. Abnormal longitudinal peak systolic strain in asymptomatic patients with type I diabetes mellitus. Echocardiography 2019; 36(3): 478-485.

https://doi.org/10.1111/echo.14257

28. El Razaky O, El Amrousy D, Elrifaey S, et al. Three-dimensional speckle tracking echocardiography: Is it the magic wand in the diagnosis of subclinical myocardial dysfunction in children with type 1 diabetes mellitus? Echocardiography 2018; 35(10): 1657-1663.

https://doi.org/10.1111/echo.14095

29. Jędrzejewska I, Król W, Światowiec A, et al. Left and right ventricular systolic function impairment in type 1 diabetic young adults assessed by $2 \mathrm{D}$ speckle tracking echocardiography. Eur Heart $\mathrm{J}$ Cardiovasc Imaging 2016; 17(4): 438-446.

https://doi.org/10.1093/ehjci/jev164

30. Hensel KO, Grimmer F, Roskopf M, et al. Subclinical alterations of cardiac mechanics present early in the course of pediatric type 1 diabetes mellitus: A prospective blinded speckle tracking stress echocardiography study. J Diabetes Res 2016; 2016. https://doi.org/10.1155/2016/2583747

31. Jørgensen PG, Jensen MT, Mogelvang R, et al. Impact of type 2 diabetes and duration of type 2 diabetes on cardiac structure and function. Int J Cardiol 2016; 221: 114-121.

https://doi.org/10.1016/j.ijcard.2016.07.083

32. Bouthoorn S, Valstar GB, Gohar A, et al. The prevalence of left ventricular diastolic dysfunction and heart failure with preserved ejection fraction in men and women with type 2 diabetes: A systematic review and meta-analysis. Diab Vasc Dis Res 2018; 15(6): 477-493. https://doi.org/10.1177/1479164118787415

33. Di Cori A, Di Bello V, Miccoli R, et al. Left Ventricular function in normotensive young adults with well-controlled type 1 diabetes mellitus. Am J Cardiol 2007; 99(1): 84-90.

https://doi.org/10.1016/j.amjcard.2006.07.063

34. Karamitsos TD, Karvounis HI, Dalamanga EG, et al. Early diastolic impairment of diabetic heart: The significance of right ventricle. Int J Cardiol 2007; 114(2): 218-223.

https://doi.org/10.1016/j.ijcard.2006.02.003

35. Mátyás $C$, Kovács A, Németh BT, et al. Comparison of speckle-tracking echocardiography with invasive hemodynamics for the detection of characteristic cardiac dysfunction in type-1 and type-2 diabetic rat models. Cardiovasc Diabetol 2018; 17(1).

https://doi.org/10.1186/s12933-017-0645-0

36. Ahmed TA, Ahmed YA, Arafa Al, et al. Detection of occult right ventricular dysfunction in young Egyptians with type 1 diabetes mellitus by two-dimensional speckle tracking echocardiography. Indian Heart J 2018; 70(5): 665-671. https://doi.org/10.1016/j.ihj.2018.06.019 37. Kosmala W, Przewlocka-Kosmala M, Mazurek W. Subclinical right ventricular dysfunction in diabetes mellitus - An ultrasonic strain/strain rate study. Diabet Med 2007; 24(6): 656-663.

https://doi.org/10.1111/j.1464-5491.2007.02101.x

38. Tadic M, Vukomanovic V, Cuspidi C, et al. The relationship between right ventricular deformation and heart rate variability in asymptomatic diabetic patients. J Diabetes Complications 2017; 31(7): 1152-1157. https://doi.org/10.1016/j.jdiacomp.2017.04.007

39. Nemes A, Piros GÁ, Lengyel C, et al. Complex evaluation of left atrial dysfunction in patients with type 1 diabetes mellitus by threedimensional speckle tracking echocardiography: Results from the MAGYAR-path study. Anatol J Cardiol 2016; 16(8): 587-593.

https://doi.org/10.5152/AnatolJCardiol.2015.6225

40. Acar G, Akcay A, Sokmen A, et al. Assessment of atrial electromechanical delay, diastolic functions, and left atrial mechanical functions in patients with type 1 diabetes mellitus. J Am Soc Echocardiogr 2009; 22(6): 732-738. https://doi.org/10.1016/j.echo.2009.03.028

41. Porpáczy A, Nógrádi Á, Kehl D, et al. Impairment of left atrial mechanics is an early sign of myocardial involvement in systemic sclerosis. J Card Fail 2018; 24(4): 234-42.

https://doi.org/10.1016/j.cardfail.2018.02.012

42. Tadic M, Ilic S, Cuspidi C, et al. Left and right atrial phasic function and deformation in untreated patients with prediabetes and type 2 diabetes mellitus. Int J Cardiovasc Imaging 2014; 31(1): 65-76. https://doi.org/10.1007/s10554-014-0536-3

43. Grandi AM, Piantanida E, Franzetti I, et al. Effect of glycemic control on left ventricular diastolic function in type 1 diabetes mellitus. Am J Cardiol 2006; 97(1): 71-76.

https://doi.org/10.1016/j.amjcard.2005.07.110 